\title{
ULIL AMRI AUTHORITY ON LIMITATION OF CONGREGATIONAL WORSHIPS IN THE PANDEMIC OF COVID-19 IN PERSPECTIVE OF FIQH SIYASAH
}

\author{
Mustafa \\ Faculty of Sharia and Islamic Law of IAIN Bone, Indonesia \\ mustafassymh90@gmail.com
}

\begin{abstract}
This article discusses the issue of limiting worship of Muslims in Indonesia, during the COVID-19 pandemic, which is regulated by Ulil Amri in Indonesia, namely the Government and Majelis Ulama Indonesia. In the regulation of restrictions on worship, it is not implemented as it should. There is a group of Muslim communities, which do not comply with the policy. This article is a literature study with a qualitative approach. The data in this study were produced from literature processing from various views of fuqaha, which is viewed from the perspective of figh siyasah. The results of the study concluded that Ulil Amri has full authority on social and ijtihadi (furu) issues, but not on the subject matter (ushul) of religion because it is the authority of Allah SWT as al-Shari '(maker of the Shari'a). Included in the Ulil Amri authority is issuing policies in preventing and overcoming the spread of the coronavirus in Indonesia, by implementing a policy of limiting worship, based on the fatwa from Majelis Ulama Indonesia, and with regulations issued officially by the Government.
\end{abstract}

Keywords: COVID-19; Ulil Amri Authority; Worship Restrictions, Islamic Law

\section{A. INTRODUCTION}

A terrible global phenomenon emerged at the end of 2019, starting in the city of Wuhan in the Hubei Province of China. A deadly and contagious virus shook the world. Only in a few months, on Wednesday, March 11, 2020, the World Health Organization (WHO) announced the status of plague as a Pandemic that affects some of the world's population. WHO Director-General, Tedros Adhanom, called on governments in various countries to take urgent and aggressive action in dealing with Covid-19. ${ }^{1}$

In dealing with Covid-19 in Indonesia, the National Disaster Management Agency or Badan Nasional Penanggulangan Bencana (BNPB) issued a decree on determining the emergency status of the coronavirus outbreak in Indonesia, which

${ }^{1}$ Hendra Friana, "WHO umumkan Corona Covid-19 sebagai Pandemi" dalam https://tirto.id/who-umumkan-corona-covid-19-sebagai-pandemi-eEvE, Accessed on 19 July 2020. 
was set until May 29, 2020. Also, on April 13, 2020, President Joko Widodo signed a Presidential Decree Number 12 of 2020 concerning the stipulation of Covid-19 as a national disaster. ${ }^{2}$

Meanwhile, as a measure of prevention and treatment of Covid-19 in specific communities, the government, through the Ministry of Religion as part of the Covid-19 Prevention Task Force, urged Muslim communities to carry out the holy month of Ramadan at home. To clarify the appeal, on April 6, 2020, the Minister of Religion, Fachrul Razi, issued a circular letter about the guidance of the Ramadhan and Eid alFitr in the midst of the Covid-19 pandemic. $^{3}$

Previously, the Indonesian Ulema Council or Majelis Ulama Indonesia (MUI) issued several fatawa in response to the spread of Covid-19. For example, Fatwa of MUI Number 14 of 2020 concerning the establishment of worshiping activity in the Pandemic. One of the fatwa issued is allowing the public to replace Friday prayers with Dzuhur (midday) prayers at home. Not only Friday prayers are forbidden, but also all types of worship that are gathering crowds or congregations, such as five-time prayers, tarawih prayers, Eid prayers, corpse management, and other worship are prohibited, with notes that the area is included in the category of red zones or zones with high and uncontrolled transmission rates. ${ }^{4}$

The fatwa received support and approval from most Islamic mass organizations, such as Nahdlatul Ulama and Muhammadiyah. Not only in Indonesia, but the fatwa is also in line with a fatwa from several Islamic countries such as Egypt, Kuwait, Oman, Iran, the United Arab Emirates, Qatar, Bahrain, and the kingdom of Saudi Arabia. Even in the Haram Mosque and the Nabawi Mosque, the restrictions on congregational

\footnotetext{
${ }^{2}$ Humas BNPB, "Status Keadaan Darurat Bencana Wabah Penyakit Akibat Virus Corona di Indonesia" dalam https://bnpb.go.id , Accessed on 19 July 2020.

${ }^{3}$ Retia Kartika, "Berikut Imbauan Kemenag soal Pelaksanaan Ibadah Ramadhan di Tengah Pandemi Corona" dalam https://www.kompas.com/tren/read/2020/04/17/191036065, Accessed on 19 July 2020.

${ }^{4}$ Adrian Pratama Taher, "Fatwa MUI saat pandemi Corona, salat jumat bisa diganti salat zuhur" dalam https://tirto.id/fatwa-mui-saat-pandemi-corona-salat-jumat-bisa-diganti-salat-zuhur-eFJc, Accessed on 19 July 2020.
} 
worship is also applied. Syekh Abdul Aziz said, a Grand Mufti, stated that if the outbreak continues during Ramadan, then the Eid Al-Fitr prayer would be carried out at home. Saudi Arabia has also postponed the implementation of the Hajj and Umrah this year. ${ }^{5}$

Like other Islamic countries, Indonesia also issued a kind of regulation in terms of restrictions on worship that are gathering people or congregation (mainly in the mosque). The government seems to lack courage in implementing these regulations. So that all of these regulations are limited to the government's appeals and/or recommendations. Likewise, the existence of $\mathrm{MUI}$ as a representation of Indonesian Islamic scholars in issuing fatwa also does not have binding legal force on Muslims. Only Muslims who wish to comply with the fatwa makes the fatwa as a reference.

On the other hand, some people oppose the MUI fatwa because they follow the opinion of certain groups. They ignored the fatwa while continuing to carry out worship in the congregation, even though it was in the area of the uncontrolled spread of Covid-19. The most obvious example, in this case, is the plan to organize the World's ljtima Ulama in the Asian zone in Gowa Regency, South Sulawesi Province. Although then the event was canceled, there was a group of Jama'ah present in Gowa Regency at the time, led to the emergence of a new cluster of Covid-19 deployments that spread to several regions in Indonesia. ${ }^{6}$

Although then the event was canceled, there was a group of Jama'ah present in Gowa Regency at the time, led to the emergence of a new cluster of Covid-19 deployments that spread to several regions in Indonesia.

This, of course, increases bias with efforts to handle the Covid-19 in Indonesia. This country has a legitimate government, and this constitutional state is a state of

\footnotetext{
${ }^{5}$ Pandasurya Wijaya, "Ramadhan di Tengah Pandemi, Antisipasi berbagai Negara Islam Hadapi Virus Corona" dalam https://m.merdeka.com/dunia/ramadan-di-tengah-pandemi-antisipasi-berbagainegara-islam-hadapi-virus-corona-html, Accessed on 19 July 2020.

${ }^{6}$ Rachmawati, "Menyoal Klaster Ijtima Ulama Gowa, dari Peserta Covid-19 menyebar ke Jawa Tengah hingga Kalimantan" dalam https://regional.kompas.com/read/2020/04/25/09390001. Accessed on 20 July 2020
} 
law. ${ }^{7}$ Besides, there is $\mathrm{MUI}$ as a representation of Islamic scholars in Indonesia. Nevertheless, there are still parts of Muslims who follow other opinions, in the midst of the emergency conditions of Covid-19.

This situation can be seen in Max Weber's theory of power, which is divided into traditional, legal-rational, and charismatic. ${ }^{8}$ Based on Weber's theory, the state of worship authority exists on many parties, depending on the community groups. Thus, it is very likely that most Muslims will judge their authority of worship to be in the MUI and the government as Ulil Amri in this country. However, not a few groups that make their local leaders or certain groups as authorities, because of their charisma.

Although the theory is placed by Weber in the context of political power, this will be corresponding if it is related to the forms of social action and social relations that characterize various community groups because power is inseparable from authority. Therefore, Weber's category is an abstraction, not a concrete reality. According to Bashori Alwi, charisma sometimes affects well-established social phenomena, because it is a specific phenomenon, so the type of valid power is traditional and rational-legal power ${ }^{9}$. Therefore, whether the authority of worship, according to the theory, is in accordance with fiqh siyasah.

With regard to what is underlying that there are Muslims who do not obey the government, or why the MUI fatwa does not become the primary reference in the application of worship of all Muslims in Indonesia, even though both of them can be categorized as Ulil Amri in this country. This is interesting to discuss scientifically, which is formulated through an Islamic study approach, about the form of Ulil Amri's authority according to the provisions in fiqh siyasah. In addition, the extent of Ulil

${ }^{7}$ Undang-undang Dasar Negara Republik Indonesia Tahun 1945, Pasal 1 Ayat 3.

${ }^{8}$ Dana Williams, Max Weber: Traditional, Legal-Rational, and Charismatic Authority (Ohio: The University of Akron Akron, 2003), p. 1.

${ }^{9}$ Bashori Alwi, “Otoritas Ibadah: Antara Cita dan Fakta” Hakam: Jurnal Kajian Hukum Islam dan Hukum Ekonomi Islam, Vol. 1, Number 1, June 2017, p. 8 
Amri's authority in regulating the restrictions on worship in the Muslim community during the Covid-19 Pandemic in Indonesia.

\section{B. METHODS}

This research is a literature study with a qualitative approach. The data were produced from the literature of various fuqaha views in figh books, as well as reviews from experts on the authority of Ulil Amri in organizing worship. Including the restriction of worship in the period of the Covid-19 outbreak, which was reviewed in terms of the Fiqh Siyasah.

The data obtained were then analyzed inductively, with the aim of abstraction and concluding the research results from various reviews of fuqaha's opinion on the authority of Ulil Amri in organizing worship activity. Then drew a general conclusion about the authority of Ulil Amri in organizing the worship activity of the perspective of fiqh siyasah.

\section{RESULTS AND DISCUSSION}

\section{The Position of Religion and State in Islam}

The discussion of the position of religion and state in Islam has been explained in various classical literature, as dinun wadaulah. That religion and state are two inseparable things. Because in Islam, religious law is the basis in governing and community life. Moreover, there are some provisions of the Shari'ah that require the establishment of a state. Imam Al-Ghazali stated that the establishment of religion depends on the establishment of worldly affairs and its system. ${ }^{10}$

Therefore, Islam is very concerned about political order and good governance. When tracing the concept of a state (ummah) in Islam, the source is found in the QS. Ali Imran / 3 verse 110:

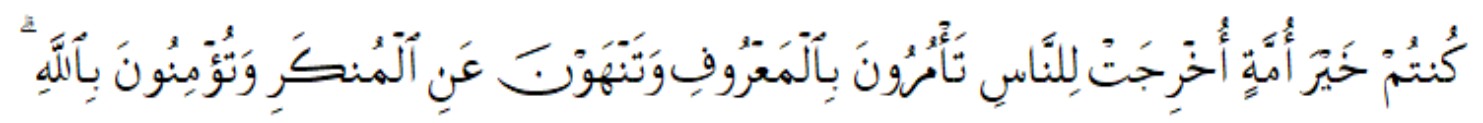

Translation: "You are the best nation produced [as an example] for mankind. You enjoin what is right and forbid what is wrong and believe in Allah. If only

\footnotetext{
${ }^{10} \mathrm{Abu}$ Hamid al-Gazali, Al-Wasit fi al-Mazhab, Jil. VII (Kairo: Dar al-Salam, 1997), p.7.
} 
the People of the Scripture had believed, it would have been better for them. Among them are believers, but most of them are defiantly disobedient."

The contemplation of the verse, according to Abul A'la al-Maududi, that the ummah (state or nation) desired by the Quran is a state that guarantees the freedom of each individual in spreading virtue and conducting social justice in order to prevent humans from being hostile to each other and to create a stability of a state. ${ }^{11}$

In the Islamic concept, the state also takes care of the private interests of citizens related to the world and the hereafter. Because of the interests are not appropriately regulated, they will collide with the interests of the community. According to Lukman Arake, individual interests are united with certain rules (religion and state), with the aim of protecting the interests of the community, because by protecting the interests of the community, it means that it has safeguarded individual interests. ${ }^{12}$ Until the position of religion and state in Islam is an integral unity.

\section{The terminology of Ulil Amri according to the Mufassir}

Many Mufassir give different meanings about the phrase of Ulil Amri in QS. anNisa' / 4 verse 59:

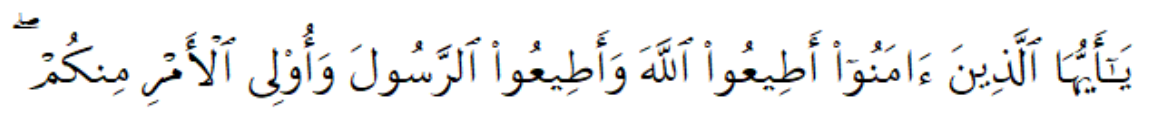

Translation: "O you who have believed, obey Allah and obey the Messenger and those in authority among you. And if you disagree over anything, refer it to Allah and the Messenger, if you should believe in Allah and the Last Day. That is the best [way] and best in the result."

Al-Tabari quotes four opinions regarding the phrase of Ulil Amri, namely: 1) Ulil Amri which means al-Umara'; 2) Ulil Amri means ahlul 'Ilmi wal fiqhi; 3) Ulil Amri means așhāab Muhammad peace is upon him; and, 4) Ulil Amri are Abu Bakr and Umar. However, Al-Tabari chose an opinion that interpreted Ulil Amri with the meaning of

\footnotetext{
${ }^{11}$ Abul A'la al-Maududi, Nazariyah al-Islam wa Hadyuhu fi Assiyasah Walqanun Waddustur (Jeddah: Addar Assaudiyah, 1985), p. 46.

${ }^{12}$ Arake, Lukman. "AGAMA DAN NEGARA PERSPEKTIF FIQH SIYASAH." Al-Adalah: Jurnal Hukum dan Politik Islam 3.2 (2019): 79-116.
} 


\section{Mustafa}

umara' because of the authentic hadith of the Prophet. The command to obey umara' is as long as they command obedience to Allah SWT and bring benefit to the people. ${ }^{13}$

According to Ibn Kathir, the verse shows that the meaning of Ulil Amri is general; both umara' and ulama (scholars). ${ }^{14}$ In another case with Al-Zamakhsyari, he confirms that the meaning of Ulil Amri specifically to umara al-Haq, umara al-saraaya, and ulama. ${ }^{15}$

Meanwhile, according to Fakhr al-Din al-Razi, the meaning of Ulil Amri is ahlu al-Halli wa al-'Aqdi from Muslims. ${ }^{16}$ Likewise, according to Muhammad' Abduhm, the meaning of Ulil Amri is the congregation of ahlu al-Halli wa al-'Aqdi

from Muslims, namely the umara' (government) and hukama (ruler), ulama (scholars), and all community leaders. ${ }^{17}$

It can be concluded that all mufassir agree on the government or the authorities (other terms) as one of the meanings of Ulil Amri. Others also accommodate ulama (ahlul 'Ilmi wal fiqhi) as Ulil Amri. So it is clear that the Caliphs of Abu Bakr and Umar could enter the second category, both as rulers and also scholars.

Regarding the Companions of the Prophet, according to Yunahar llyas, for the other Companions of the Prophet, not all of them were categorized as Ulil Amri, unless what was meant was after the death of Rasulullah SAW, Ulil Amri fell to friends as the first generation after Rasulullah SAW. ${ }^{18}$

\footnotetext{
${ }^{13} \mathrm{Abu}$ Ja'far Muhammad ibn Jarir al-Tabari, Jami' al-Bayan 'an Ta'wil Ayi al-Qur'an, Juz. VIII (Beirut: Dar al-Fikr, 1988.), h. 496-501.

${ }^{14}$ Mahmud ibn 'Umar Al-Zamakhsyari al-Khawarizmi, al-Kasysyaf 'an Haqa'iq al-Tanzil wa 'Uyun al-Aqawil fi Wujuh al-Ta'wil, Jil. I (Beirut: Dar al-Fikr, 1977), h. 524.

${ }^{15}$ Mahmud ibn 'Umar Al-Zamakhsyari al-Khawarizmi, al-Kasysyaf 'an Haqa'iq al-Tanzil wa 'Uyun al-Aqawil fi Wujuh al-Ta'wil, Jil. I (Beirut: Dar al-Fikr, 1977), h. 524.

${ }^{16}$ Fakhr al-Din al-Razi, Mafaatih al-Ghayb, Jil. X (Beirut: Dār al-Fikr, 1995), h.113.

${ }^{17}$ Sayyid Muhammad Rasyid Rida, Tafsir al-Qur'an al-Hakim (Tafsir al-Manar), Jil. V (Beirut: Dar al-Fikr, 1973), h.147.
}

${ }^{18}$ Yunahar Ilyas, “Ulil Amri dalam tinjauan Tafsir” Jurnal Tarjih, Vol. 12, Number 1, 2014, h. 47. 
al-Razi and Muhammad Abduh put forward a more precise and more general category of Ulil Amri, which is ahlu al-Halli wa al-'Aqdi from Muslims. If the Ulil Amri agree on a matter, then all people must obey it, as long as it does not conflict with the commands of Allah and His Messenger.

\section{Ulil Amri Authority in a State}

As a successor for prophetic duties, together, Ulil Amri (umara' and ulama) occupy a high and noble position. This is because of the large responsibilities and the heavy workload they carry, in safeguarding religion and organizing the lives of the people. The position is as mentioned in QS. an-Nisa' / 4 verse 59: " O you who have believed, obey Allah and obey the Messenger and those in authority among you. Moreover, if you disagree over anything, refer it to Allah and the Messenger, if you should believe in Allah and the Last Day. That is the best [way] and best in the result." They occupy the third position, after Allah and His Messenger.

Therefore, the authority of Ulil Amri in making or establishing a law is limited. According to Yunahar llyas, because the word al-amr has the form ma'rifah or definite, the authority of the authorities is limited to social matters only, not to matters of faith or pure religion. The issue of aqeedah (ushul) must be returned to the Qur'an and the hadith of the Holy Prophet. ${ }^{19}$

Lukman Arake mentioned that only al-Syari' (Allah SWT.) had the authority to make the laws. A mujtahid (ulama) is only limited to displaying religious law. However, in the case of ijtihadiyah, for Ulil Amri has the authority, even if the problem has become ijma', then it automatically becomes part of Islamic law. ${ }^{20}$

In Islamic Figh (Jurisprudence), the principles of the Ulil Amri authority have been arranged. In the book of al-Ahkam al-Sulthaniyyah by Imam al-Mawardi, the principles have been explained, namely: a) Maintaining the agreed foundations of religion; b) Uphold justice, so that no one feels persecuted; c) Uphold the sharia law,

${ }^{19}$ Yunahar Ilyas, "Ulil Amri dalam tinjauan Tafsir" ..., h. 48.

${ }^{20}$ Arake, Lukman. "OTORITAS KEPALA NEGARA DALAM MENENTUKAN SUATU KEBIJAKAN PERSPEKTIF SIYASAH SYAR'IYAH." Al-Bayyinah 3.2 (2019): 166-189. 
so that the religion of Allah. Moreover, human rights are maintained; d) Maintaining the security and safety of the people by protecting their territory from enemy interference and things that can threaten their lives. So that they can live well and their souls and properties are guaranteed; e) Carry out jihad against those who are hostile to Islam, so that they embrace Islam or binding peace agreement; and finally, $f$ ) Control the management of state finances. ${ }^{21}$

Meanwhile, the rights for Ulil Amri will be obtained if the Ulil Amri has run its authority and obligations by giving the people's rights and fulfilling the rights of Allah. Therefore, the people or specifically Muslims are obliged to obey and support the policies that are not contradicted with the Syaria. ${ }^{22}$

In al-Mawardi's explanation, the authority possessed by Ulil Amri is so broad. Actually, besides being understood as a principle in Ulil Amri's authority, Ulil Amri also should carry out this principle.

Therefore, if Ulil Amri carries out these obligations, then set rules or policies for the benefit and welfare of Muslims, and does not contradict with the sharia. Then the people must obey these rules. A person who is negligent and ignores these rules can be considered sinful, and even Ulil Amri is given the authority to sanction the person in the form of ta'zir punishment.

\section{The Policy on the Restriction of Worship in Congregation during the Covid-19 Pandemic.}

In the context of Indonesia, the umara' and ulama as Ulil Amri in this country, they have authority in accordance with their respective duties and functions. If umara as Ulil Amri in the aspect of political leadership, then ulama as Ulil Amri in the aspect of religious affairs. If both Ulil Amri agrees on a matter, then all people must obey it, as long as it does not conflict with the commands of Allah and His Messenger.

\footnotetext{
${ }^{21}$ Imam al-Mawardi, al-Ahkam al-Sulthaniyyah (Cet. 1; Tt: Dar al-Fikr, 1960), h.15 - 16.

${ }^{22}$ Imam al-Mawardi, al-Ahkam al-Sulthaniyyah..., h.17.
} 
If there is a difference of opinion about the understanding of religious texts, then it is resolved by using the rules of khilafiyah (difference) that already exist in the Islamic scientific Study. The umara' (government) is not allowed to intervene in the matter of understanding religious texts, because this is not an area of authority. Nevertheless, if there are differences of opinion in social and state matters, the government can decide which opinion will be followed-included in maintaining the order and safety of citizens. ${ }^{23}$

For example, in determining the beginning of Ramadan and the month of Shawwal, in relation to the implementation of the fasting and Eid prayer, the hisab and rukyat methods are left to the ulama or religious leaders (MUI). However, the matter of determining the day of Eid and other things out of context religious scholarship was decided by the government (Ministry of Religion). ${ }^{24}$

Likewise, in an effort to prevent the transmission of the Covid-19 outbreak, previously, the Indonesian Ulema Council issued MUI Fatwa Number 14 of 2020 concerning the organization of worship in the Covid-19 situation. In the fatwa, there are several provisions regarding the rukhsah (replacement) of some worship services such as Friday prayers, five-time congregational prayers, sunnah tarawih prayers, and other congregational worship, replaced by worship at homes. However, it is only applied for the region that included in the category of red zones or zones with high and uncontrolled transmission rates. ${ }^{25}$

In this case, of course, there will be certain scholars or groups who differ on this issue, because this is a form of Islamic scientific flexibility. Therefore, if there is such a thing, that there are scholars who claim not to leave the congregation worship in the

\footnotetext{
${ }^{23}$ Yunahar llyas, "Ulil Amri dalam tinjauan Tafsir" ..., h. 49.

${ }^{24}$ Faisal Yahya, "Ketaatan kepada Pemimpin dalam Penetapan Awal Ramadhan dan Hari Raya di Indonesia menurut Hadis" Jurnal Deliberatif Jurnal Ilmiah Hukum, Vol. 2. Number 2, December 2017, h. 228

${ }^{25}$ Adrian Pratama Taher, "Fatwa MUI saat pandemi Corona, salat jumat bisa diganti salat zuhur" dalam https://tirto.id/fatwa-mui-saat-pandemi-corona-salat-jumat-bisa-diganti-salat-zuhur-eFJc, Accessed on 19 July 2020.
} 
midst of Covid-19's emergency conditions, then the people should ignore the fatwa like this. Because it can be considered to underestimate a danger, besides that, it can also be regarded as defiance of Ulil Amri's policy.

Another matter of concern, the government as much as possible emphasizes the legitimacy of the fatwa of the Indonesian Ulema Council (MUI), not just an appeal but with a ban or restriction on the implementation of worship in a congregation, of course, based on the fatwa of $\mathrm{MUI}$ and still paying attention to the regional distribution category of Covid-19. This is a part of maintaining maqasid sharia, and this certainly does not contradict the provisions of Allah and His Messenger.

Then there are no other choices for Muslims in Indonesia not to follow and not carry out restrictions on worship in congregation issued by Ulil Amri in this country because it is obligatory for Muslims to obey Ulil Amri. On the contrary, a person will be given a ta'zir punishment if he does not obey Ulil Amri as long as they order something right and beneficial.

\section{CONCLUSIONS AND SUGGESTIONS}

In conclusion, in fiqh siyasa, a person or a group of Ulil Amri has full authority on social issues and ijtihadiyah ( $\left.f u r u^{\prime}\right)$ issues, but not on the issue of religious principal (ushul) because it is the authority of Allah as al-shari' (The Law Maker). Issuing policies in preventing and overcoming the spread of Covid-19 in Indonesia are included in the Ulil Amri authority, both with the Fatwa of the Indonesian Ulema Council and with regulations issued officially by the government.

Besides the issue of the reopening or the revocation of social restrictions, including worship in a congregation, Muslims should wait for Ulil Amri's decisions and policies, namely the Government and the Indonesian Ulema Council, so that the Covid19 outbreak did not recur and was truly overcome. 


\section{REFERENCES}

\section{Books and Journals:}

Alwi, Bashori. "Otoritas Ibadah: Antara Cita dan Fakta" Hakam: Jurnal Kajian Hukum Islam dan Hukum Ekonomi Islam, Vol. 1, Number 1, June 2017.

Arake, Lukman. "AGAMA DAN NEGARA PERSPEKTIF FIQH SIYASAH." Al-Adalah: Jurnal Hukum dan Politik Islam 3.2 (2019): 79-116.

Arake, Lukman. "OTORITAS KEPALA NEGARA DALAM MENENTUKAN SUATU KEBIJAKAN PERSPEKTIF SIYASAH SYAR'IYAH." Al-Bayyinah 3.2 (2019): 166-189.

Al-Gazali, Abu Hamid. Al-Wasit fi al-Mazhab, Vol. VII. Kairo: Dar al-Salam, 1997.

Ibnu Katsir, Isma'il al-Qurasyi ad-Dimasyqi, Tafsir al-Quran al-'Azim. Vol. IV. Riyadh: Dar 'Alam al-Kutub, 2004.

Ilyas, Yunahar. "Ulil Amri dalam tinjauan Tafsir" Jurnal Tarjih, Vol. 12, Number 1, 2014.

Al-Maududi, Abul A'la. Nazarivah al-Islam wa Hadyuhu fi Assiyasah Walqanun Waddustur. Jeddah: Addar Assaudiyah, 1985.

Al-Mawardi Imam, al-Ahkam al-Sulthaniyyah. Edition 1; Tt: Dar al-Fikr, 1960.

Al-Razi, Fakhr al-Din. Mafaatih al-Ghayb, Vol. X. Beirut: Dār al-Fikr, 1995.

Rasyid Rida, Sayyid Muhammad. Tafsir al-Qur'an al-Hakim (Tafsir al-Manar), Vol. V. Beirut: Dar al-Fikr, 1973.

Al-Tabari, Abu Ja'far Muḥammad ibn Jarir. Jami' al-Bayan 'an Ta'wil Ayi al-Qur'an, Juz. VIII. Beirut: Dar al-Fikr, 1988.

Williams, Dana. Max Weber: Traditional, Legal-Rational, and Charismatic Authority. Ohio: The University of Akron Akron, 2003.

Yahya, Faisal. "Ketaatan kepada Pemimpin dalam Penetapan Awal Ramadhan dan Hari Raya di Indonesia menurut Hadis". Jurnal Deliberatif Jurnal Ilmiah Hukum, Vol. 2. Number 2, December 2017.

Al-Zamakhsyari, Mahmud ibn 'Umar al-Khawarizmi. al-Kasysyaf 'an Haqa'iq al-Tanzil wa 'Uyun al-Aqawil fi Wujuh al-Ta'wil, Vol. I. Beirut: Dar al-Fikr, 1977.

\section{Online Source (Internet):}

Undang-undang Dasar Negara Republik Indonesia Tahun 1945, Pasal 1 Ayat 3. (The 1945 Constitution of the Republic of Indonesia, Article 1 Paragraph 3)

Adrian Pratama Taher, "Fatwa MUI saat pandemi Corona, salat jumat bisa diganti salat zuhur" dalam https://tirto.id/fatwa-mui-saat-pandemi-corona-salat-jumatbisa-diganti-salat-zuhur-eFJc, Accessed on 19 July 2020. 
Hendra Friana, "WHO umumkanCorona Covid-19 sebagai Pandemi" dalam https://tirto.id/who-umumkan-corona-covid-19-sebagai-pandemi-eEvE, Accessed on 19 July 2020.

Humas BNPB, "Status Keadaan Darurat Bencana Wabah Penyakit Akibat Virus Corona di Indonesia" dalam https://bnpb.go.id , Accessed on 19 July 2020.

Pandasurya Wijaya, "Ramadhan di Tengah Pandemi, Antisipasi berbagai Negara Islam Hadapi Virus Corona" dalam https://m.merdeka.com/dunia/ramadan-ditengah-pandemi-antisipasi-berbagai-negara-islam-hadapi-virus-corona-html, Accessed on 19 July 2020.

Rachmawati, “Menyoal Klaster ljtima Ulama Gowa, dari Peserta Covid-19 menyebar ke Jawa Tengah Kingga Kalimantan" dalam https://regional.kompas.com/read/2020/04/25/09390001. Accessed on 20 July 2020

Retia Kartika, "Berikut Imbauan Kemenag soal Pelaksanaan Ibadah Ramadhan di Tengah Pandemi Corona" dalam https://www.kompas.com/tren/read/2020/04/17/191036065, Accessed on 19 July 2020. 